\title{
CARTEL PARTY: AN ANALYSIS STUDY
}

\author{
Yeni Sri Lestari \\ Department of Sociology \\ Faculty of Political and Social Sciences \\ University of Teuku Umar, Meulaboh \\ yenilestari24@yahoo.com
}

\begin{abstract}
This article analyzes the history and impact of the presence of party cartel in a system of government, where the concept of party cartel is still little known and recognized by the public, but the assessment of the case as well as issues related to the party cartel and its impact has long been studied since 1995 through writing Richard S. Katz and Peter Mair. The emergence of the cartel party into the political dynamics of its own for a system of government in many countries. This study becomes important as the development of democracy and the increasingly high rate of corruption of a country are often motivated by the cartel party lobbies. Therefore, this article will discuss what is meant by the party cartel? How the party can form a cartel? What is the impact of the cartel party his form for a system of state administration?. This study found that the cartel party is a collection of political parties that basically have different ideologies but, for the achievement of the interests of a group of people they work together at the expense of public interests. Party cartel formed based on the needs of the political elite to gain and maintain their power to minimize the differences of opinion among the party elite. Party cartel works by forming a coalition of political parties that dominate the government and the party's presence in a country cartel hamper the democratic system of government and a country.
\end{abstract}

Keywords--cartel party; political parties; and the party elite

\section{INTRODUCTION}

The study of the cartel party first appeared in the writings of Katz \& Mair (1995), which deeply examine more closely the dependence between the political parties and the state. This dependence encourages political parties to form a collusion in a state institution that aims to harness the resources of the state to ensure their collective survival. Political parties are in collusion came to be known as a party cartel.

The existence of the party cartel in the system of government, often invisible, namely the existence of the party cartel was not shown publicly where they gather together to form an agreement (collusion), but the party of these cartels often reveal their appearance as a collection of political parties work together to form coalition of political parties in state institutions.

Cooperation between political parties in the governance system of a country is an absolute thing that must exist, either as decision makers as well as the proposer. Coalition of political parties in government is basically a form of cooperation of political parties which have the aim to jointly support the government that is running, and is balanced by the presence of the opposition political party group who chose to become a party outside the ruling party so as to realize the mechanism of checks and balances in a system of government.

The number of corruption scandals, legal, social, economic, and political issues as well as other countries which often involves political party elites provides a challenge for political parties in maintaining the credibility of their party. Therefore, in every process of resolving issues related to the political elite is often not resolved until completely or only get mild sanctions even allowed to disappear, it is not because of the intervention of the party cartel which has considerable power in every aspect of life state.

Ignorance of the general public about the existence of the cartel party has given 
more space and provide opportunities for the existence of the cartel party in carrying out their agendas. Be aware that the existence of the cartel party a bad impact to the system of government of a country, especially giving huge losses to the public. Therefore, this article will analyze the party cartel and the impact arising from the existence of the cartel in a state party.

The study of the emergence of the party cartel in Indonesia have been discussed by Kuskridho Ambardi through his doctoral dissertation entitled The Making of Indonesian multiparty System: A Cartelyzed Party System and Its Origin in 2008 and an article by Dan Slater titled Indonesia's Accountability Trap: Party Cartels and Presidential Power after Democratic Transition in 2004. Both these writers have expounded the signs of the emergence of cartels in the political party system in Indonesia.

This study seeks to describe more specifically and in detail on the definition of a cartel party to the impact that will result from the existence of the cartel party in a country, especially Indonesia. In analyzing this cartel party, the case studies of some of the governance issues in Indonesia, especially during the reign of Susilo Bambang Yudhoyono and Jusuf Kalla (2004-2009) will be presented in order to facilitate understanding of this study.

\section{MATERIAL AND METHODS}

The research methodology in this study used qualitative methods that provide exposure and a description of the object being studied through a series of descriptions of the issues that are the subject of this study. Model description in the discussion of this study aims to provide an overview, summary, the situation of the various conditions that arise from analyzing business cartel party, so it will be concluded as a result than this study.

\section{RESULTS AND DISCUSSION}

\section{A. The concept of the Cartel Party and Initial Appearance in politics Systems}

Richard S. Katz and Peter Mair in 1995 in his article entitled Changing Models of Party Organization and Party Democracy: The Emergence of the Cartel Party examines the phenomenon of the birth of a new party known as the party of the cartel. Katz and Mair saw that through in the middle of 20th century, the development of democracy in the West not only provide impact real in terms of social change, but it extends to the political sphere, especially with regard to the problems faced by a political party.

The issue often faced by political parties can never be separated from matters of state, this then lead to changes in the relationship between political parties and the state. Where, before political parties and individual countries to perform its role without having a strong bond and tend to serve the interests of the community, but now the relations that present among the political parties and the country more to the pattern of the symbiotic relationship that cannot be separated between them mainly by the party cartel.

Political party in a democratic country should have a huge relationship with the community. This is because the voice or the support provided by the community, the existence of a political party will be stronger in a country. In contrast, on public support for political parties, political parties act as intermediaries between the community and the state as a representative of the broader community in expressing their aspirations to the state.

Chart 1. Relationship of Political Parties Public-State

Before the establishment of the Cartel Party

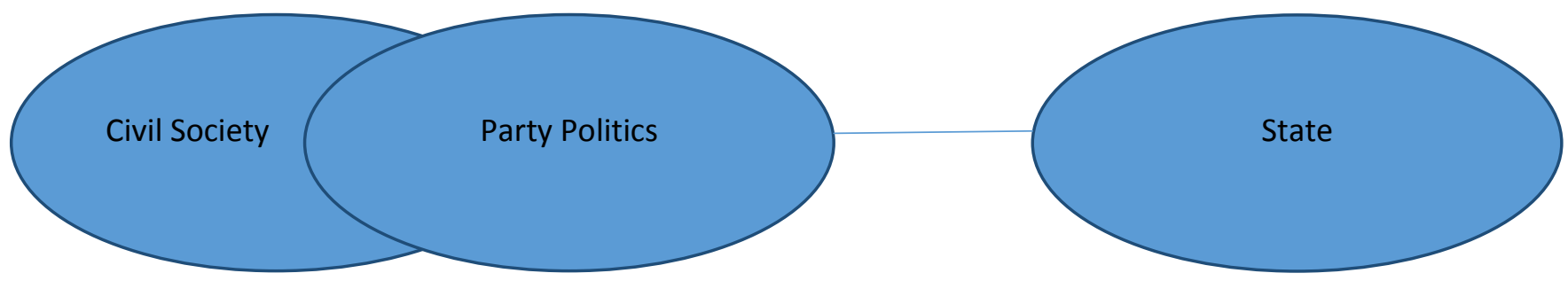


Destination changes made by political parties as representatives of the community to the goal to seek and gain power has changed the map of the position of the political parties. Political parties no longer consider the existence of society as a determining factor for power, it caused the gap relationship between political parties and society deepened. Political parties tend to approach the state to seek and gain power.

Chart 2. Relations Society of Political Parties Countries

After the formation of the Party Cartel

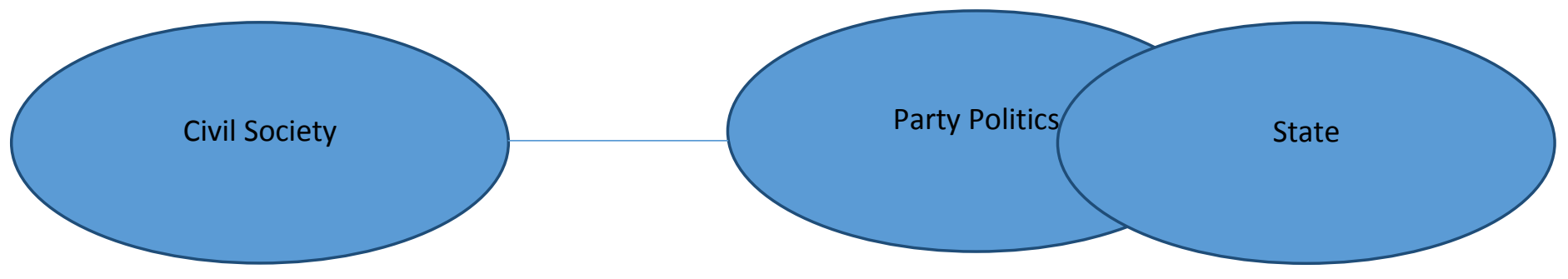

A shift in the relationship between society, political parties, and the state has emphasized the dependence of political parties to the state and not to the public. This occurs due to changes in the interest of political parties to get more financial resources ensured by becoming an ally country compared to being an ally of society.

The existence of the cartel party very depending on the country promises a big advantage for the political parties that are members of the cartel party. Party cartel can benefit from the financial resources of the country due to the cartel party elites have controlled most of the system of government, the judiciary and even the state security agencies.

Often, in a corruption case involving the elites of political parties will not be found to the party elite is severely punished. In fact, it is often the case law involving the political elite would escape the law or if the punishment, then the sentence is not proportionate.

This happens because of the role of party cartel to protect members of his party and the party of power possessed by the cartel to buy a state law.

Party first appeared cartel due to the amount of funds required by the political parties to follow the electoral process (the election). Political party funding sources are limited, requiring political party elites have other options to raise capital political parties.
Capital of political parties in the elections is increasing primarily to finance capital good candidates campaign leaders who fought in the area of the executive and legislative branches.

The development of democratic systems in many countries provides an opportunity for the community great freedom in determining his fate, one of which is to choose a leader. One of the comprehensive development of democracy is felt today is the emergence of an electoral system that is varied in a society which is supported by the more modern system that campaign as well.

Modernizes an electoral system has created various kinds of campaigns that are increasingly attractive. Attempt to gain support not only do monotonically course is only through the speeches of the candidates, but the use of media, especially electronic media such as television and radio campaign is a place which is quite time consuming enormous costs. This then causes the amount of effort that must be made by a political party to seek financial resources to finance political capital amount is not small.

Approached of political parties to the state as a solution to seek and obtain the financial resources. Political parties strive to always support the state institutions to gain a strategic position in the government. For those political parties that are members of the state party in progress has the advantage of positions gained while the political parties 
that took a position as an opposition party certainly will not get a foothold in the state institutions, which means the opposition parties will not get and feel the benefit that comes from the country's wealth.

Position and power of political parties in state institutions, especially the wet state institutions, provide an opportunity to leverage their position taking the financial resources of either country to be like salary and illegally, such as corruption, collusion and nepotism to make a profit. Party member cartel has the same agenda for control of the country's wealth, making illegal means to get it will be pursued, it is in accordance with the principle of party cartel that prioritizes cooperation with minimizing conflicts between members, so that each agenda which has been designed by a party member cartel of course, upon agreement together.

More and more members of a political party that has a position or positions in state institutions, the revenue for the financial political parties will also be getting bigger, this is due to the provision for party members holding positions in state agencies to set aside some of their earnings to the party treasury. Great demands of finance political parties, political parties often leader of elites who have positions in the institutions of corruption in order to meet political party treasury.

The amount of the advantages of being part of the party's rule began giving effect to many political parties to tend to provide support to the party winning the elections without considering the differences in ideology that was striking among them. Based on that, the ideology of political parties are increasingly blurred due to their desire to form an inter-party cooperation to minimize the conflict in order to gain personal benefit or group.

Electoral systems for cartel party is no longer considered to play an important role for their survival, this is because the position between the election winner and the loser does not give any meaning if the cartel party has been formed. Collusion has been formed in the cartel party to provide security for the elites of political parties because regardless of ideological differences between political parties, members of the party elite cartel will certainly get their share of power in the country.
Ideological competition between political parties during the election rampant visible only. If the election results have been announced, the political parties that were previously competing to be flattened themselves to the party winning the elections and joined as a party of government supporters, a phenomenon that is currently rife in the countries that embrace multi-party system is the tendency of the growing number of government party and hardly any opposition party.

Collusion through a coalition formed party cartel in government basically done on the basis of protecting the interests of the party cartel in finding and mastering the financial resources of the state, to achieve the smooth coordination and sustained the party cartel sought to dampen political competition between them by maximizing cooperation favorable between groups of political parties in the cartel party. Missing or not the involvement of opposition parties in a system of government a country has helped eliminate checks and balances in the democratic process in the political field.

\section{A. Case of Cartel Party}

Indonesia, is one of the third world countries continue to experience growth in terms of democracy, not least in the political sphere. As a country with a multi-party system, competition between political parties should be higher, but it did not happen after the emergence of a collusion between the majority of the political parties to form a partnership, which was known as a party cartel.

The emergence of the cartel party first in Indonesia when the shaft is formed by Amien Rais and the whole party in the Majelis Permusyawaratan Rakyat (MPR) unless the Partai Kebangkitan Bangsa (PKB) jointly overthrow President Abdurrahman Wahid (Gus Dur) in 2000-2001. Referred to as the cartel party group because they were dissatisfied with the government of Gus Dur, particularly their desire to dissolve the Assembly, so that Gus Dur is considered as a threat to the survival of political parties at that time.

The success of the shaft MPR dropped Abdurrahman then followed by the 
appointment of Megawati Sukarnoputri as a substitute Gus Dur, who served from 20012004. Coalition of political parties that have successfully dropped the Gus Dur and Megawati as president then occupy strategic positions in state institutions.

Megawati's leadership as a president in Indonesia significantly raises some disadvantages that should be regarded as a violation of law, but it did not happen. Some indications of state losses during the leadership of Megawati is the case of tanker VLCC (Very Large Crude Carrier) which does not exist is not clear which has estimated state loss of USD 26-56 million, but that thing has never been underreported as a loss to the state by the audit results conducted by Badan Pengawas Keuangan (BPK).

The absence of further investigation of the existence tanker owned by Perseroan Terbatas (PT). Pertamina either from politicians or the state (BPK) indicate a dirty game and an agreement made by the elites of political parties controlled almost all sectors of state institutions. Mastery and influence that elite political parties who are members of the cartel party on important sectors of the country aiming to ease their way to achieve their interests.

Not only BPK that can be controlled by a cartel, legal institutions, especially the judiciary was controlled by the cartel party. Moreover, state institutions through some very loud to resolve legal issues involving members of the party elite cartel slowly be criminalized causes, the law is not clear, it is most evident when the reign of SBY-JK in 2004-2009 and SBY-Boediono in 2009-2014.

Indonesian elections held in 2004 became one of the defining point is getting the good of democracy in Indonesia. Changes in the electoral system of indirect election into direct election marks the latest political dynamics in Indonesia. 2004 election was followed by five pairs of presidential candidates as vice president in the first round and the second round was only followed by two pairs of candidates, namely MegawatiHasyim and Soesilo Bambang YudhoyonoJusuf Kalla.

During the presidential election of 2004, there were two camps party coalition that supports different couples, first is the National Coalition consisting of the Partai Demokrasi
Indonesia Perjuangan (PDIP), Partai Golongan

Karya (Golkar), Partai Persatuan

Pembangunan (PPP) andPartai Damai Sejahtera (PDS ) supporting the MegawatiHasyim, the second is the Popular Coalition consists of the Partai Demokrat (PD), Partai Kesejahteraan Sosial (PKS), Partai Amanat Nasional (PAN) as well as several other smaller parties who provide support to the SBY-JK.

The results of the presidential election in 2004 won a pair of candidates SBY-JK, so Populist Coalition faction automatically becomes a party group of government, while the National Coalition faction declared itself as a party outside the government (the opposition). However, this did not last long due to the Golkar and PPP finally pressed the party to support the government, while the PDIP and PDS still declare themselves as an opposition party but not too plays a key role in any policy set by the leadership of SBY-JK.

Aprroached of government party Golkar faction to not be separated from the important role that $\mathrm{JK}$ is one of the Golkar party elite were respected. Growing support and cooperation among parties in parliament against the government and thus provide opportunities for achieving cooperation through support and avoid conflict, it is then signaled the strengthening cartel party phenomenon in Indonesia.

Dan Slater (2004) stated that direct democratic process in Indonesia has brought Indonesia into practice "Trap Accountability", namely the failure of the role of political parties in exercising checks and balances in government. The loss of the ideology of competition in the middle of the party and strengthening the formation of cartels has eliminated the appearance of opposition.

Competition ideology on direct elections in 2004 only visible when the elections take place, but when the party winning the elections has been set many parties to get minority declared themselves to join and support the party of government. At the beginning of the election has been apparent their ideologies and political directions that differ among the contending parties, but the change in direction of party support as if depict their hidden interests to be achieved through the incorporation into the state party. 
The political battle in the elections of 2004 it was clear classify the two coalition of political parties that have a very clear distinction in terms of ideology and couples are supported. However, the change in direction coalition with aprroaches several parties that opposed the government party indicates cooperation to be achieved, it is characterized also by the appointment of ministers from each party supporters as well as a change in the cabinet (reshuffle) Volume II, where a growing number of party members put into the position of state institutions.

SBY leadership of the second period was in 2009-2014 in which pairs with Boediono SBY. This second period indicates the magnitude of the party coalition government was formed, in which nearly $80 \%$ of political parties in parliament, the parties supporting the government made up of six major parties, namely PD, Golkar, PKS, PAN, PPP and PKB, groups of the coalition better known as the Sekretariat Gabungan (Setgab).

Sharpening the practice of party cartel in the governance system in Indonesia at this time is very evident from the emergence of several legal issues involving Apra party officials government. The case of Bank Century bailout funds amounting to Rp. 6.7 Trillion is not clear where the flow of funds to date, the tax arrears cases involving three large companies owned by Abu Rizal Bakrie (Golkar chairman), and the criminalization of KPK chairman Antasari Azhar is some question of law which the direction is not clear until now.

The legal inquiry against the above cases then disappear coincided with the emergence of Setgab. It is then further indicated cartel practices among government elites at that time, when examined further on the Bank Century case obviously there is a violation of law and indications of political corruption while the tax case involving Bakrie companies have markedly provide financial loss to the state.

Coinciding with the establishment Setgab consisting of a large coalition government parties have caused such cases no longer heard the news. even the efforts of institutions Komisi Pemberantasan Korupsi (KPK) to continue to ensnare the political elite who do corruption should be hindered by the emergence of various attempts to criminalize the high-ranking Commission at that time, especially with the jailing of Chairman of the Commission is active at the time, Antasari Azhar allegedly as the mastermind behind the murder of the Director of PT. Putra Rajawali Bantaran, Nasrudin Zulkarnain without credible evidence.

The legal case involving the political elite especially the corrupt practices that many have an impact on state finances are often not taken seriously even not to ensnare the main actors. This is what reflects their games carried by the party elite cartel in regulating and controlling all aspects of government aims to continue to maintain their power, the efforts made not only take financial resources of the state but also seeks to control every state institutions so that their interests will be maintained, no exception by doing dirty game as it is evident in the various attempts to criminalize KPK officials.

\section{B. The impact of the Cartel in a State Party}

The amount of influence and power cartel party against state institutions with the aim of taking and reap the wealth of the country, of course, give a very bad impact for a country. The adverse effects of their specific cartel party is perceived to the stability of a government, especially with regard to the welfare of society at large.

The first impact of the cartel party is to give a great chance against the practice of political corruption. The definition of political corruption by Rose-Ackerman (1999), Manzetti \& Wilson (2007) is a process in relation between the unauthorized use of use of state resources to maintain and expand its political power by those who hold political office in the government.

Political corruption can be interpreted as an act of corruption by elites of political parties in a country. In Indonesia, many corruption cases involving the political elite, especially involving members of the board, more and more cases of corruption that makes the MPs as a suspect in both the central and regional levels illustrate the increasingly widespread practice of political corruption that aims to enrich themselves or a group of his party.

One cause of the rampant political corruption among parlementary members in 
Indonesia due to the amount of capital that must be issued by the campaign of candidates to contest the election process. This then makes the victory legislators as a container to take away the financial resources of the state by illegal roads, and to simplify the matter, the party formed a cartel.

Party cartel presents a great opportunity for the occurrence of political corruption in Indonesia. Many cases of corruption involving the political elite found guilty by the court, but some major cases involving high-ranking political parties, then the legal process seem slow even not tried at all. For example, the leadership of Megawati as president left some legal issues indicated as corruption but it is unclear legal process such as the presence of tankers PT. Pertamina and the loss of Indosat shares.

Political corruption cases greater is the case of Bantuan Likuiditas Bank Indonesia (BLBI) that occurred in 1998, in which the state provides financial assistance to 23 banks with a total aid of Rp. 164 trillion, and the case of Bank Century bailout funds provided by the state amounting to Rp. 6.7 trillion. In BLBI case, the flow of money cannot be accountable to the state indicated to have involved some state officials in the era of 1997-2004, as president, ministers, parliamentarians, and even central bank officials were suspected of committing political corruption using BLBI.

The legal process BLBI continues to be followed, especially after the establishment of the Commission as an institution of anticorruption eradication in Indonesia. In 2007, a series of process of investigating rogue elements of government officials during the year 1997 to 2004 is planned to be inspected, and some former officials of that era have been examined by the Commission which eventually in 2009 set Aulia Pohan as a suspect, while high-ranking other political barely touched by the Commission, when in the process of investigating this case coupled with their attempt to criminalize high-ranking Commission.

The case of Bank Century also allegedly been misused for the benefit of a political group. Vagueness of the flow of funds and the emergence of some donors, the presidential campaign that is Century Bank customers indicate foul play in this case. However, the investigation into the case is lost little by little when the compromises of political parties in parliament are built through the establishment Setgab. Of the several examples of cases that have been mentioned, gives a real picture of how the cartel working party to seek and obtain financial resources earmarked for the state of their group interest.

Second, the impact of the cartel party for a country is to eliminate the checks and balances in government. Democratic system of government characterized by checks and balances between the policy makers and policy controller state. However, the background of cooperation between the parties in government in order to obtain financial resources by gaining positions in state institutions has caused the loss of the opposition as a counterweight to government parties.

Real case of loss of checks and balances in the Indonesian system is very visible on the SBY government in two periods of 2004-2009 and 2009-2014. In both periods the SBY administration, coalition contained in parliament more known as a grand coalition, said to be almost as large as most political parties in parliament become parties supporting the government in the SBY era, while the presence of opposition parties was minimal and did not play a significant role in the reign of the time.

Thirdly, the presence of the cartel party led to the demise of the popular vote. Shifting patterns of political party relationship of society towards dependence on the state, causing the voice and aspirations of the people is no longer important for political parties. Political parties no longer build a relationship with the community as the main foundation for creating a system of fair governance and wise, serve as the country's closest ally by political parties to organize the system of government so that the administration of justice for the people gradually began to diminish and even disappear.

Fourth, the presence of the cartel party gives false hope to the democratic system. Ideals of Indonesia as a country that is heading a transition to democracy is just a mere dream, the magnitude of cooperation and lack of competition among the political elite in government has led policy-making 
tend to side with their group alone, there is no longer a democracy that had been dreamed, when electoral process is an event party of the people has been largely restricted heartbeat just for political parties.

\section{CONCLUSION}

a) The cartel party is cooperation between political parties in a country that is trying to eliminate competition from ideological differences of each party that aims to seek, obtain, and maintain the financial resources of the state for the benefit of the group.

b) The formation of a cartel party in a country that needs a huge backdrop of the political party on the sources of funds into supporting a political party to win the election process.

c) Party cartel led to the growing political corruption among state officials.

d) Party cartel eliminate checks and balances within a government.

e) Party cartel led to the death of the popular vote as the deciding state sovereignty.

f) Party cartels provide false hope to the democration system aspired by many people.

The study of the cartel party in Indonesia is still very low, but the fact of existence of cartel party in Indonesia is increasing. Many legal cases in Indonesia led by the party of the cartel, one of which is the increasing number of political corruption among officials indicated that the political party cartel became one of the causes of the culture of political corruption among the political elite. Moreover, the cartel party in a developing country would continue or be terminated through various means aimed at re-establishing democratic systems of a country.

\section{REFERENCES}

Dan Slater. (2004). Indonesia's accountability trap: party cartels and presidential power after democratic transition. Research library No. 78: 61.
Dan Slater. (2006). The ironies of instability in Indonesia. Berghahn Journal Volume 50, issue 1: 208-213.

John, G Peters, and Susan Welch. (1978). Political Corruption in America: A Search For Definitions and A Theory, on if Political Corruption is in the Mainstream of American Politics Why is it Not in the Mainstream of American Politics Research?. The American Political Science Review, 72 (3): 974984.

Joseph Nye. (1989). Corruption and Political Development: A Cost-Benefits Analysis. In Arnold J. Heidenheimer, Michael Johnston and Victor T LeVine. Political Corruption: A Handbook. New Brunswick: Transaction Publisher.

Kuskridho Ambardi.(2008). The making of the Indonesian multyparty system: $A$ cartelized party system and its origin. The Ohio State University: dissertation.

Kuskridho Ambardi. (2011). Meninjau ulang konsep dan gejala kartelisasi partai di Indonesia. Diskusi melawan politik kartel. Jakarta: 27 Oktober.

Kuskridho Ambardi. (2013). Kompetisi dan kartelisasi: akar masalah dan pencegahannya. Diskusi KPK "sistem politik berintegrasi. 11-12 September

Manzetti, Luigi and Carole J. Wilson. (2007). WHy do Corrupt Government Maintain Public Support. Journal of Comparative Political Studies. Volume 20, pp: 949970.

Melnyk, Mykola. 2009. Political corruption: essence, factors, countermeasures. National security and defence journal Number 7: 67-72.

Omar Ibrahim \& Izham Hakimi Hamdi. (2013). Sistem kepartian di Indonesia pasca Orde Baru: Persaingan atau perkartelan. Jurnal Jebat Volume 40 (1): 155-176.

Persson, Torsten, Guido Tabellini and Franceso Trebbi. (2003). Electoral Rules and Corruption. Journal of the European Economic Association. Volume 1, Issue 4, pp: 958-989.

Richard S. Katz \& Peter Mair. (1995). Changing models of party organization and party democracy: the emergence of the cartel 
party. Sage Publications. Party Politics Volume, 1, Number 1, pp 5-28.

Richard S. Katz \& Peter Mair. (2009). The cartel party thesis: A restatement. Articles Volume 7 Number 4: 753-766.

Robert Klitgaard. (1998). Membasmi korupsi. Jakarta: Yayasan Obor Indonesia.

Robert Klitgaard, Ronald Maclean-Abroa and H. Lindsey Parris. (2002). Penuntun pemberantasan korupsi dalam pemerintahan daerah. Jakarta: Yayasan Obor Indonesia dan Partnership for Governance Reform in Indonesia.

Susan Rose-Ackerman. (1999). Corruption and Government: Causes: Consequences and Reform. Cambridge, United Kingdom: Cambridge University Press. 